\title{
The Effect of Experiential Learning Models Toward Writing Skills of Narration Primary School Student
}

\author{
Risma Nuriyanti, Rahman, Ernawulan Syaodih, Prana Dwija Iswara, Agus \\ Muharam
}

Universitas Pendidikan Indonesia, J1. Dr. Setriabudhi No. 229, Kota Bandung

email: nuriyantirisma@upi.edu

\begin{abstract}
Learning to write in elementary school is currently not getting serious attention. This results in the poor quality of students' narrative writing. This study aims to determine the effect of experiential learning models on the narrative writing skills of elementary school students. The method used is a quasiexperimental research design with a nonequivalent control group design. The population in this study was the fourth-grade students at the UPI Lab school Elementary School, amounting to 47 students and divided into two classes, namely the experimental class and the control class. The results showed that there were significant differences between the experimental class posttest and the control class. From these results, it can be concluded that the experiential learning model significantly influences the narrative writing skills of elementary school students. Thus students get meaningful learning and teachers get alternative learning to write for students to create meaningful learning with analytical assessment in the form of content, content, information, grammar, and mechanical organization.
\end{abstract}

Keyword: experiential learning model, writing skill of narration, primary school student

\section{Introduction}

Today's $21^{\text {st }}$-century learning aims to prepare students for an increasingly complex environment and life. Students must master the tasks that require higher-order thinking skills, one of which is complex communication, namely interacting with others to convey, obtain and direct information, ideas and ideas (Afandi \& Sajidan, 2018, p. 14). This can be obtained by students one of them from learning, especially learning Indonesian where in Indonesian language learning includes four components of skills namely listening skills, speaking skills, reading skills, and writing skills that are interrelated and very inseparable (Nuriyanti \& Rahman, 2018 ). The four skills are interconnected in a variety of ways. If one component of the skill is not possessed by a student it will affect other skills. Writing skills are also a component of skills that get the attention of observers and are considered important in education (Satriani, 2012).

Bearing this in mind, there are many problems related to writing skills in the field. Students still find it difficult to win ideas in writing. students are still confused when they are about to start writing, and students have difficulty in developing a creative id that has not yet led to the compilation of narrative writing from starting to determine ideas, plot, and points of view in writing. The problem that is often encountered is the lack of conformity of student writing with the title or theme of the writing. Supriyanto 
(2009) revealed that from the results of an IEA survey regarding the reading and writing abilities of Indonesian children around $50 \%$ of students in primary schools in six provinces under the Primary Education Quality Improvement Project (PEQIP) could not compose. From these results, it can be said that one of the factors in the low writing skills of students is due to the low interest in reading students. In line with the opinion of Hartati (2017) who argues that low student interest in reading results in a lack of student writing quality.

Research in the field of narrative writing skills is in great demand by researchers. Nuriyanti \& Rahman (2018) states that by applying the collaborative learning model influences students' narrative writing skills. However, in this study, the mastery of concepts related to writing material is very lacking. This is evident from the results of mechanical related research, namely spelling and the use of punctuation that is still experiencing many errors. To overcome this need the application of learning models that can guide students to master the concept of writing well. This is reinforced by the opinion of Moidady (2015) that learning to write narration should be through teacher guidance from the initial stages until students can write essays well. This is evidenced by student essays have increased. However, in the implementation of this strategy, the learning process focuses on the teacher. This is evident from the results of the study described in terms of the activities of teachers and students, teachers are still dominant in learning. If you look at the curriculum approach used in Indonesia, the teacher is only a facilitator of learning and the student-centered learning process.

Bearing this in mind the need for learning that is not only centered on the teacher by applying a student-centered learning model, as revealed by Nuryanti (2016) that with student-centered learning, it is qualitatively better if only focused on the teacher because students have a greater share in determining writing creatively. However, in this study students tend to be confused in developing the contents of the essay because the learning process is less stimulated by the activity created. Therefore in learning to write requires a model or method that can create meaningful experiences and interaction between teachers and students equally.

Based on the problems that have been explained related to writing skills and student writing results. This is the background of the implementation of quasi-experimental research which aims to see the effect of experiential learning models on narrative writing skills of elementary school students. Through the application of experiential learning models, students actively think about what is learned and then how to apply what has been learned in students' situations. This method directs students to gain more experience through active and personal involvement. Besides, through the application of the model of exclusive learning students can develop creative ideas into coherent and clear writing. This is in line with the opinion of Hosnan (2014) which states that the experiential learning model can encourage and develop students' creative thinking processes. Addition experiential learning models are not only concerned with learning outcomes but will be the process of learning through experiences that contribute to students on an ongoing basis. 
Thus, experiential learning models place learning as a conscious and deliberate action centered on learning experiences (Kolb \& Kolb, 2009). The Experiential learning model is a learning model that uses the experience as a medium of learning or learning. In line with the opinion of Kolb (2014) "a common usage of the term experiential learning defines it as a particular form of learning from the lived experience, often contrasted it with lecture and classroom learning. It is further explained that learning through this experience provides a set or situation of learning in the form of the involvement of true experience and new understanding or learning processes emerge (Hamalik, 2001). the purpose of experiential learning models is to provide meaningful learning experiences to students so that they can change the way students think and improve the skills possessed by students in their own way from real experiences that are natural brands (Kolb, 2014).

The purpose of this study was to determine the effect of experiential learning models on the narrative writing skills of elementary school students. The sample in this study was fourth-grade students of 47 elementary school students. The experiential learning model consists of four stages, namely concrete experience, reflection observation, the formation of abstract concept and generalization, and testing experimentation which is carried out continuously for six times in the experimental class. This research will be an alternative learning narrative writing for teachers, especially elementary school teachers. Not only that teachers get new knowledge related to analytical writing narrative evaluation in terms of organization of content, content, information, grammar, and mechanics.

\section{Methodology}

This study uses a quantitative approach with a quasi-experimental research method design nonequivalent control group design. This quasi experimental study was used to determine differences in the ability of classes that were treated and classes that were not treated. According to Sugiono (2016, p. 77), in this study, there will be two groups that are not chosen randomly. Both were then given a pre-test to determine the initial state and differences between the experimental and control groups. A good pretest result is the value of the experimental group in the control group did not differ significantly. Following is an overview of the research design listed in table 1

Table 1. Nonequivalent Control Group Design

\begin{tabular}{ccc}
\hline $\mathrm{O}_{1}$ & $\mathrm{X}$ & $\mathrm{O}_{2}$ \\
\hline $\mathrm{O}_{3}$ & - & $\mathrm{O}_{4}$ \\
\hline
\end{tabular}

Annotation:

$\mathrm{O}_{1} \quad$ : Pretest Class Experiment

$\mathrm{O}_{2} \quad$ : Posttest Class Experiment

$\mathrm{O}_{3} \quad$ : Pretest class control

$\mathrm{O}_{4} \quad$ : Posttest class control

$\mathrm{X} \quad$ : Treatment Experiential learning models

- $\quad$ : the class that is not given treatment 
The population in this study were all fourth-grade elementary school students in the city of Bandung. The selected sample was the fourth-grade students of the UPI Bumi Siliwangi Pilot Laboratory, totaling 47 students, 24 students from the experimental class and 23 students from the control class. the sample selection technique uses a purposive sampling technique because there are two groups of quasi-experimental research that are not randomly selected (Sugiono, 2016). This is reinforced by the opinions of Cresswell (2013) and Crano, Brewer, \& Lac (2014) who state that quasi-experiments involve the placement of participants but not random placement in groups because experiments cannot create groups artificially for their experiments.

\subsection{Learning Condition}

Learning is carried out six times learning, each learning is carried out two hours of learning ( $2 \times 35$ minutes). The class situation is good, in terms of room area, seating, lighting in a bright state, air circulation and all students are ready to learn. so overall the class is good enough. friendly and literate class design, seen in every corner there is a place for children to read. to facilitate the teacher in delivering material related to narrative writing. The teacher gives a narrative text to each student by identifying intrinsic elements in the essay. It aims to make students understand the elements that exist in narrative writing with a variety of themes and storytelling.

\subsection{Instrumen Research}

The research instruments used in this study are (1) Learning Implementation Plan based on the 2013 curriculum. In learning activities, there are stages of experiential learning models for narrative writing learning. (2) Writing tests in the form of instructions for writing narration in the form of personal experiences carried out at the pretest and posttest. Evaluation of narrative writing skills is measured by rubric assessment of narrative writing skills is measured from five aspects namely (1) content organization; (2) contents; (3) information; (4) grammar, and (5) mechanical. These five aspects are assessed on a scale of 1-5.

\section{Result And Discussion}

In this study, learning is carried out six times. previously students were given a pretest to find out the initial abilities of students both in the experimental class and in the control class. The similarity of students 'initial abilities in narrative writing skills shows the absence of researchers' bias in determining the experimental class and the control class. From the pretest results obtained the average value of narrative writing skills of students in the experimental class was 38.83 , while in the control class was 44.13 . The results are said to be still low. That is because the narrative writing material is rarely given intensively to students. Not only that, when the pretest was held the atmosphere in both classes was noisy because there were still many students who did not understand 
writing narratives. This was reinforced by Muhtadi, A. (2005) that a less conducive classroom climate would affect student learning outcomes.

The initial ability equation which is seen from the pretest value of the experimental class and the control class becomes the reason for the researcher to provide treatment. The treatment given to each of these classes is a different treatment. At this stage of treatment, students get learning six meetings. After the two classes are given different treatments, then the final test or posttest is carried out. After doing a posttest on both classes. The posttest results showed a change, the average value of narrative writing skills of each class both the experimental and control classes had increased compared to before. The average posttest value of the experimental class given treatment by applying the experiential learning model was 71.16, while the control class that did not get the treatment gained 50.26.

Based on these results, to prove the research hypothesis that there is an influence of experiential learning models on students' narrative writing skills statistical tests are performed first, namely (1) data normality test between the experimental class and the control class; (2) homogeneity test between the experimental class and the control class, and (3) hypothesis testing. The following is a test of the normality of experimental and control class data both pretest and posttest in detail in table 1

Table 1. Test Of Normality

\begin{tabular}{llll}
\hline Result & & Pretest & Posttest \\
\hline Writing skills of narration & Experiment & 0.137 & 0.582 \\
& Control & 0.155 & 0.789 \\
\hline
\end{tabular}

In table 1, the results of the pretest and posttest normality test both the experimental class and the control class when compared with a significance level of more than 0.05 . it can be concluded both the pretest value and the posttest value of the experimental class and the control class are normally distributed. These results prove that the sample represents a normal population based on the pretest and posttest scores of students from the control class and the experimental class. other than that the results are required to do prametrict tests. This is consistent with the opinion Azzalini \& Capitanio (1999) that data that has a normal distribution has a normal distribution, with the profile considered to represent the population. Next, the test of the heterogeneity of the data between the experimental class and the control class both pretest and posttest are detailed in table 2

Table 2. Test Of Homogeneity

\begin{tabular}{llll}
\hline Result & Df & Pretest & Posttest \\
\hline Writing skills of narration & 45 & 0.519 & 0.095 \\
\hline
\end{tabular}

Table 1 shows that the homogeneity test results of both the pretest and posttest data between the experimental class and the control class when compared with a significance value of more than 0.05 . Then it can be concluded that the pretest and posttest values of the experimental and control classes have homogeneous variance. 
Based on the results of normality and homogeneity tests of narrative writing skills data. Pretest and posttest values are derived from data that are normally distributed and have homogeneous variances. Therefore to test the hypothesis in this study using parametric statistics, namely by using the two-difference test, the t-test. The t-test was carried out compared to the pretest and posttest mean of the experimental class and the control class. The following results of the pretest and posttest homogeneity tests of the experimental class are in table 3

Table 3. Independent Sample Test

\begin{tabular}{clll}
\hline \multirow{2}{*}{ Result } & Df & Pretest & Posttest \\
\cline { 2 - 4 } & \multicolumn{3}{l}{ Sig.(2-tailed) } \\
\hline Writing skills of narration & 45 & 5.297 & 0.00 \\
\hline
\end{tabular}

Based on the data in table 3, showing a pretest significance value of more than 0.05 ie 5.297, it can be concluded that there is no difference between the experimental class and the control class. In contrast to the significant value of posttest less than 0.05 which is 0.00 , this means that the posttest of narrative writing skills of students in the experimental class who were treated by applying the experiential learning model and the control class that did not get treated there were differences or there were significant influences.

Based on these results, it was found that the treatment given by applying experiential learning models affected students' narrative writing skills. This is because the experiential learning model has a positive effect on students' narrative writing skills, especially in organizing content, producing diverse words, and expressing student experience into writing. the results obtained are in line with the results of research Rahman, et al (2017) which concluded that there is a significant effect of experiential learning models on students' writing abilities.

The experiential learning model provides benefits to students' memory abilities in understanding an experience students have experienced in their daily activities (Estes, 2004). This has become one of the learning resources that can develop students' writing skills (Rahman, 2019). Besides building creative ideas and increasing student interest in learning to write that is difficult to master. As stated by Rosalina (2018) \& Kellogg (2008) which states that students' narrative writing skills are relatively very complex and difficult to master. This is consistent with the reality that occurred during the research where certain students complain when writing. Besides addition, it requires the ability to think, namely creative thinking, especially in a good language in order to be able to express ideas and ideas in a writing.

Through experiential learning models, students practice to producing good narrative texts based on the stages of the model. The stages are in the form of concrete experiences, reflections, conceptualizations, and applications. Stages of concrete experience as a process where students get information or new knowledge then reflected individually or in groups. At this stage, good communication is needed between students and teachers. In line with the opinion of Rahman (2018a) that teachers should 
have good communication skills so that students understand what is explained, such as asking questions and giving opinions. It aims to stimulate ideas that are owned by students. After that, at the conceptualization stage students can compose sentences and ideas in the form of ideas that have been reflected as well as finding errors in the work of students in writing sentences in the writing outlined. Stages in the experiential learning model also help students to carry out active learning activities that enable students to learn new skills, new attitudes or new ways of thinking.

At the stages of experiential learning model learning there is not directly a writing learning process that makes students understand the stages of writing that starts from pre-writing activities, drafting, revising, editing, and publishing (Meitikasari, 2018). The fifth activity is carried out in learning to write to construct text by involving interactions that occur simultaneously. In line with the opinion of Akhadiah (in Setiawan \& Ngadiri, 2019) argues that writing is a process in expressing ideas into a written language which in practice is manifested in several stages that are overall. Writing is also interactive, collaborative, and cooperative (Brown, 2001; Llorente., Gómez \& García-Peñalvo, 2016).

Learning conditions with experiential learning models are in accordance with the principles of language learning, namely the principle of constructionism which considers that the learning process is addressed as creativity in managing and connecting experiences and knowledge to form a wholeness (Al-Jarrah, JM, Mansor, Talafhah, \& Al-Jarrah, TM (2019) Not only is the experiential learning model in accordance with the functional principles of language learning, that the teacher is not the only provider of information and learning resources (Magfiroh, 2013), so the process of writing learning that requires students to be able to become a creative learning that involves students actively.

Besides the successful application of experiential learning models to students' narrative writing skills. Based on the findings there is one indicator of writing skills that did not experience a significant increase, namely mechanical indicators. These results affect the achievement of the average value of students. Where almost all the students are wrong in writing spelling and punctuation. That is because students lack mastering the rules of writing and need special assistance or are guided in training students to write with the rules of writing correctly. This is in line with the opinion of Halidjah, S. et al (2013) which states that by guiding writing students will understand the writing rules that they will slowly pour in a writing.

\section{Conclusion}

Based on the results of the above explanation, it can be concluded that the experiential learning model statistically has a significant influence on the narrative writing skills of elementary school students in grade IV of the UPI Pilot Laboratory. This is evidenced by the research hypothesis test between the posttest control and posttest experimental differences. The significance value is less than 0.05 , which is 0.00 . This means that there are differences in the posttest scores of students' narrative writing skills in the experimental class and in the control class. The results can be seen the average value of 
the experimental pretest got 38.83 increased after being given a treatment that is at the posttest to 71.16 . Whereas in the control class the average score of pretest getting 44.13 increased in the posttest to 50.26. So it can be concluded that the experiential learning model significantly influences narrative writing skills but lacks in increasing students' abilities on mechanical indicators that have certain restrictions that are adjusted with Indonesian Spelling. Therefore there needs to be a guided strategy to improve these indicators

\section{Reference}

[1] Afandi \& Sajidan, R. (2018). Stimulasi Keterampilan berpikir tingkat tinggi. Sukarata: UNS Press

[2] Al-Jarrah, T. M., Mansor, N., Talafhah, R. H., \& Al-Jarrah, J. M. (2019). The application of metacognition, cognitivism, and constructivism in teaching writing skills. European Journal of Foreign Language Teaching, 4(3), 199-213

[3] Azzalini, A., \& Capitanio, A. (1999). Statistical applications of the multivariate skew normal distribution. Journal of the Royal Statistical Society: Series B (Statistical Methodology), 61(3), 579-602.

[4] Brown, H.D. (2001). Teaching by principle: an interactive approach to language pedagogy. San Francisco: Longman.

[5] Crano, W. D., Brewer, M. B., \& Lac, A. (2014). Principles and methods of social research. Routledge.

[6] Cresswell, J. W. (2013). Research Design: Pendekatan Kualitatif, Kuantitatif, dan Mixed. Yogyakarta: Pustaka Pelajar

[7] Estes, C. A. (2004). Promoting student-centered learning in experiential education. Journal of Experiential Education, 27(2), 141-160.

[8] Halidjah, S. (2013). Peningkatan Kemampuan Menulis Karangan Narasi dengan Strategi Menulis Terbimbing di Kelas IV SD. Jurnal Pendidikan dan Pembelajaran, 2(9).

[9] Hartati, T.(2017). Conferencing Approach in Promoting Writing Ability, A Classroom Action Research Study on Language Creatve Writing in Indonesia Language. Indonesia Journal of Applied Linguistics 7(2), 56-63

[10] Kellogg, R. T. (2008). Training writing skills: A cognitive developmental perspective. Journal of writing research, l(1).

[11] Kolb, D. A. (2014). Experiential learning: Experience as the source of learning and development. FT press.

[12] Kolb, Y. K. \& Kolb, D. A. (2009). The Learning Way Meta-Cognitive Aspects of experiential Learning. "Simulation \& Garning" Journal Sage Publication. 40(3), 297-327

[13] Llorente, A. M. P., Gómez, M. C. S., \& García-Peñalvo, F. J. (2016). Assessing the effectiveness of interactive and collaborative resources to improve reading and writing in English. International Journal of Human Capital and Information Technology Professionals (IJHCITP), 7(1), 66-85 
[14] Maghfiroh, L. (2013). Penggunaan Media Flashcard untuk Meningkatkan Hasil Belajar IPS pada Pembelajaran Tematik di Sekolah Dasar. Jurnal Penelitian Pendidikan Guru Sekolah Dasar, 1(2), 1-13

[15] Meitikasari, A. (2018). Experiential-Learning In Writing Class: A Suggested Teaching Practice For Islamic Universities. Pedagogy: Journal of English Language Teaching, 6(2), 97. doi:10.32332/pedagogy.v6i2.1233

[16] Moidady, N. (2015). Upaya Meningkatkan Kemampuan Menulis Karangan Sederhana Siswa Kelas IV SDN Pembina Liang Melalui Strategi Aktivitas Menulis Terbimbing. Jurnal Kreatif Online, 2(2).

[17] Muhtadi, A. (2005). Menciptakan iklim kelas (Classroom Climate) yang kondusif dan berkualitas dalam proses pembelajaran. Majalah Ilmiah Pembelajaran, 2.

[18] Nuriyanti \& Rahman. (2018). The effect od Model Collaborative Learning Assited by Media Big Book to writing Narrative Skills to Primary School Student. Proceeding International Conference on elementary Education. 1(1). 466-473

[19] Nuriyanti, R. dkk (2016).The implementation of scientific approach in improving Creative writing skills of elementary school student. Proseding Seminar Antar Bangsa PedA8

[20] Rahman, et al (2017). Model Pengajar dan Bahan Pembelajaran. Bandung: Alqa.

[21] Rahman. (2018a). Keterampilan Guru Abad 21 dalam Variabel Keprofesionalan Guru. Pendidikan Dasar. Universitas Pendidikan Indonesia.

[22] Rahman. (2019). Kecakapan Literasi di Sekolah Dasar. Pendidikan Dasar. Universitas Pendidikan Indnesia

[23] Rosalina, A. (2018). Pengaruh Metode Generating Interaction Between Schemata And Text Terhadap Kemampuan Membaca Pemahaman Dan Kemampuan Menulis Eksposisi Siswa Sekolah Dasar. Tesis. Tidak diterbitkan

[24] Satriani, I, Emilia, E, \& Gunawan, M. H. (2012). Contextual Teaching and Learning Approach to Teaching Writing. Indonesian Journal of Applied Linguistics. 2(1), 10-22

[25] Setiawan, T \& Ngadiri (2019, April). Application of Genre Based Learning Models to Improve Understanding and Writing Ability Negotiation Text for High School Students. In International Conference on Interdisciplinary Language, Literature and Education (ICILLE 2018). Atlantis Press.

[26] Sugiono. (2016). Metode Penelitian: Kuantitatif, Kualitatif, dan R\&D. Bandung: alfabeta

[27] Supriyanto, A. (2009). Mutu Pendidikan Sekolah Dasar di Daerah Diseminasi Primary Education Quality Improvement Project (PEQIP). Jurnal Ilmu Pendidikan Universitas Negeri Malang, 4(4). 